\title{
Removal of Chromium lons from Tannery Wastewater using Cactus Powder
}

\author{
WALEED H. RIMAWI*, SAFA SHAHEEN and HATIM SALIM \\ Department of Applied Chemistry, Palestine Polytechnic University, Hebron P.O. Box 198, \\ Palestinian Territories. \\ *Corresponding author E-mail: whrimawi@ppu.edu \\ http://dx.doi.org/10.13005/ojc/360118
}

(Received: November 11, 2019; Accepted: February 10, 2020)

\begin{abstract}
Leather industry consumes large amounts of chemicals, particularly toxic chromium sulfate. $30-40 \%$ of chromium used in this industry is released as a solid or liquid waste, which eventually ends up in soil and ground water. This work aims at determining the total chromium in samples of tannery wastewater and removing it using Cactus as adsorbent. Detection of chromium ( VI) and total chromium was performed spectrophotometricaly using 1.5-diphenylcarbazide reagent in addition to diazo-coupling reaction (between sulphanilic acid and $\mathrm{N}, \mathrm{N}$-dimethylaniline). The efficiency of removing chromium ions from contaminated tannery wastewater by adsorption on cactus powder was investigated by batch experiments and the effects of various parameters $(\mathrm{pH}$, adsorbent dosage and treatment time) on the percentage removal of chromium were investigated. The percentage removal obtained was $98.8 \%$ for chromium (VI) and $97.0 \%$ for chromium (III) at optimum conditions: $\mathrm{pH}=8$, adsorbent dosage equal $6.0 \mathrm{~g} / \mathrm{l}$ and contact time of $60 \mathrm{~min}$. The results of this work demonstrated for first time that removing chromium ions, especially carcinogenic chromium (VI), using cactus powder is more efficient than commonly used calcium carbonate.
\end{abstract}

Keywords: Cactus, Tannery wastewater, Total Chromium, Adsorption.

\section{INTRODUCTION}

As it is known, the leather industry consumes large quantities of water. Large amounts of different types of chemical compounds utilized in leather manufacturing processes are not completely fixed or exhausted by the skins, resulting in high chemical content in the tannery effluent. These chemicals are discharged as a waste in tannery wastewater, leading to several environmental threats in the absence of proper treatment and disposal.
The tannery wastewater is highly contaminated by various chemical pollutants including organic and inorganic compounds and salts, that results in their high toxicity and chemical oxygen demand (COD) ${ }^{1,2}$. chromium is one of major chemical constituents of the tannery wastewater with concentrations varying from 1500 to $3000 \mathrm{mg} / \mathrm{L}^{3}$, where this concentration in tannery wastewater according to Germany standards does not exceed the value $0.05 \mathrm{mg} / \mathrm{L}$ for $\mathrm{Cr}(\mathrm{VI})$ and $1 \mathrm{mg} / \mathrm{L}$ for total chromium ${ }^{4}$. Chromium in nature can be found in different chemical forms, however $\mathrm{Cr}(\mathrm{VI})$ in

This is an Open Access article licensed under a Creative Commons license: Attribution 4.0 International (CC- BY). Published by Oriental Scientific Publishing Company @ 2018 
the forms of $\mathrm{CrO}_{4}{ }^{2-}, \mathrm{Cr}_{2} \mathrm{O}_{7}{ }^{2-}$ and $\mathrm{CrO}_{3}$ is the most toxic among others, because of its strong oxidizing power, water solubility, and ability to pass though biological membranes and it is known as inhalation irritant and associated with respiratory cancer ${ }^{5-10}$.

Researchers have been intensively studying the treatment of tannery wastewater to remove chromium ions using several techniques, such as chemical coagulation ${ }^{3}$, Sedimentation techniques ${ }^{11}$, coagulation-flocculation methods ${ }^{12}$, treatment with lime and activated carbon ${ }^{13}$, adsorption onto bentonite ${ }^{14}$, amine-modified polyacrylamide ${ }^{15}$, etc. However adsorption techniques are the most widely used for chromium removal from industrial wastewaters ${ }^{4}$ due to their significant advantages like low cost, abundance, simplicity of use and efficiency, compared with other methods ${ }^{16,17}$. Large number of adsorbents are used for the treatment of tannery wastewater, some are natural and others are synthetic ${ }^{4,18}$.

Cactus (Fig. 1) is well studied for its properties and composition ${ }^{19-24}$ and widely used as biosorbent in removing different contaminants and metal ions from wastewater samples ${ }^{18,19,25-28}$. In addition to its advantages like low cost, ease of use, abundance and low sludge mass it is absolutely an eco-friendly biosorbent and safe for human health. In Palestine Cactus is historically one of the most commonly grown plants. Therefore, this work aims at studying the removal efficiency of Chromium ( $\mathrm{Cr}(\mathrm{VI}), \mathrm{Cr}(\mathrm{III}))$ from local tanneries wastewater using Opuntia ficus-indica Cactus and comparing it with the commonly used Calcium carbonate.

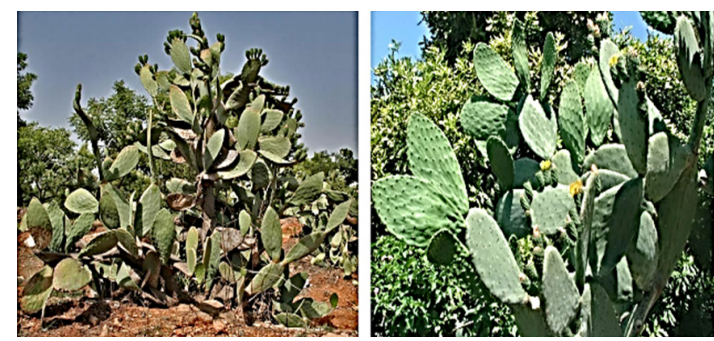

Fig. 1. Cactus Opuntia ficus-indica (p.cuctaceae) plant

\section{MATERIALS AND METHODS}

\section{Materials}

The reagents and calibration solutions were prepared from the following chemicals: acetone (Sigma Aldrich, $\geq 99 \%$ purity), glacial acetic acid (Sigma Aldrich, $\geq 99 \%$ purity), 1,5-diphenylcarbazide (alpha Acer, $\geq 99 \%$ purity), $\mathrm{H}_{2} \mathrm{SO}_{4}$ (Sigma Aldrich, 95\%-97\% purity), $\mathrm{K}_{2} \mathrm{CrO}_{4}$ (Sigma Aldrich, $\geq 99 \%$ purity) and $\mathrm{K}_{2} \mathrm{Cr}_{2} \mathrm{O}_{7}$ (Sigma Aldrich, $\geq 99 \%$ purity).

For preparation of $\mathrm{N}, \mathrm{N}$-dimethylaniline $(0.1 \%) 0.1 \mathrm{ml}$ of pure reagent was mixed with $4 \mathrm{~mL}$ of $3 \mathrm{~N} \mathrm{HCl}$ and diluted to $100 \mathrm{~mL}$ of water. Saturated bromine water $(3 \% \mathrm{w} / \mathrm{v}),(5 \%)$ solution of sulphosalicylic acid, $4 \mathrm{M} \mathrm{KOH}, \mathrm{H}_{2} \mathrm{SO}_{4}(2.5 \mathrm{M})$, $3 \mathrm{M} \mathrm{HCl}, 4 \mathrm{M} \mathrm{NaOH}$, acetate buffer $(\mathrm{PH}=4)$, hydroxylamine hydrochloride $(0.1 \%)$ and sulphanilic acid $(0.05 \%)$ were also prepared.

Tannery wastewater samples were obtained from Al-Za'tari tanneries in industrial area in Hebron/ Palestine. Triplicate samples were taken from the tanning process effluent at different height levels of collecting container into clean sterile $500-\mathrm{mL}$ glass bottles and stored at room temperature till analysis. As reported in an earlier work ${ }^{29}$, performed by our colleagues from Palestine Polytechnic University, samples of tannery wastewater from the same local leather factory were characterized as follows (COD-7.39 mg/L, TDS-60.3mg/L, TSS-17.3 mg/L).

Cactus opuntia ficus-indica (p.cuctaceae) pads were collected from Al-daheriah-Hebron $\left(31^{\circ} 24^{\prime} 27^{\prime \prime} \mathrm{N} 34^{\circ} 58^{\prime} 20^{\prime \prime} \mathrm{E}\right)$ in Palestine. Pads of Cactus were cut into thin slides, dried for 4 weeks under sun and then at $60^{\circ} \mathrm{C}$ in oven till constant mass. The obtained mass $(127 \mathrm{~g})$ was then grinded for $4 \mathrm{~min}$ and the obtained powder was kept at $-20^{\circ} \mathrm{C}$.

\section{Methods}

Determination of $\mathrm{Cr}(\mathrm{VI})$ concentration in wastewater (before treatment with Cactus powder)

Determination $\mathrm{Cr}(\mathrm{VI})$ was performed using the procedure described $\mathrm{in}^{30} .5 \mathrm{~mL}$ of wastewater was transferred to volumetric flask, sulfuric acid was to adjust $\mathrm{pH}$ at the value of 1.03 , to the obtained solution $2 \mathrm{~mL}$ of Ligand (1.5-diphenyl carbazide) was transferred then distilled water was added to achieve the volume of $50 \mathrm{~mL}$. Absorbance was read at $540 \mathrm{~nm}$ for each solution. Then the concentration of $\mathrm{Cr}(\mathrm{VI})$ was determined using the calibration curve constructed by measuring the absorbance values for solutions with concentrations of $0.1,0.3,0.5,0.7,0.9$ and $1 \mathrm{ppm} \mathrm{Cr}(\mathrm{VI})$ after treatment according to the procedure above. 
Determination of the effect of $\mathrm{pH}$ on $\mathrm{Cr}(\mathrm{VI})$ removal using cactus powder or calcium carbonate as adsorbents

Eight samples with the volume of each $33 \mathrm{~mL}$ of wastewater were transferred to beakers, then $\mathrm{pH}$ of solutions was adjusted to $2,3,5,6,7,8,9$ and 10, after that the adsorbent $(0.198 \mathrm{~g})$ was added to each. The solutions were stirred for $1 \mathrm{~h}$ and stand overnight at room temperature, and then filtered. The concentration of $\mathrm{Cr}(\mathrm{VI})$ ions was measured in the supernatant using the procedure described above. The same procedure was applied for studying the $\mathrm{Cr}(\mathrm{VI})$ removal using calcium carbonate as sorbent.

\section{Determination of the effect of adsorbent dosage} on $\mathrm{Cr}(\mathrm{VI})$ removal (using cactus powder)

Nine different samples $(0.066,0.132,0.198$, $0.264,0.330,0.396,0.436,0.528$ and $0.594 \mathrm{~g}$ ) of adsorbent were transferred to beakers containing $33 \mathrm{~mL}$ wastewater each. Solutions were stirred for $1 \mathrm{~h}$ at room temperature and $\mathrm{pH}$ of 8 and let stand overnight. Then the solutions were filtered and the concentration of $\mathrm{Cr}(\mathrm{VI})$ was measured using the procedure described above.

Determination of the effect of contact time on $\mathrm{Cr}(\mathrm{VI})$ removal (using cactus powder)

The adsorbent $(0.198 \mathrm{~g})$ was transferred to $33 \mathrm{~mL}$ of wastewater. The solution was allowed to stir at $\mathrm{pH}$ equal 8 and room temperature. Samples of supernatant were separated after different periods (30, 60, 90, 120, and 150 minutes). Samples were filtered and the concentration of $\mathrm{Cr}(\mathrm{VI})$ ions was measured using the procedure described above.

\section{Determination of Total Chromium concentration in wastewater}

The concentration of total chromium in wastewater was determined basing on the procedure presented in ${ }^{8}$. Accordingly, $500 \mu \mathrm{g}$ of wastewater was taken and transferred to $50 \mathrm{ml}$ Erlenmeyer flask then $0.5 \mathrm{~mL}$ of $4 \mathrm{M} \mathrm{KOH}$ and $1.5 \mathrm{~mL}$ of saturated bromine water were added and left for 5 minute. Then $2.5 \mathrm{M} \mathrm{H}_{2} \mathrm{SO}_{4}(0.5 \mathrm{~mL})$ and $5 \%$ sulphosalicylic acid $(0.5 \mathrm{~mL})$ were added. $\mathrm{pH}$ was adjusted to 4 using $3.5 \mathrm{~mL}$ of acetate buffer and hydroxylamine hydrochloride $(0.1 \%)$ was added. After $5 \mathrm{~min}$ sulphanilic acid $(0.05 \%)$ was added, the solution was left for $3 \mathrm{~min}$, after what $0.1 \% \mathrm{~N}, \mathrm{~N}$-dimethylaniline $(5 \mathrm{~mL})$ and $4 \mathrm{M} \mathrm{NaOH}(4 \mathrm{~mL})$ were added. Then to the obtained solution $3 \mathrm{~N} \mathrm{HCl}$ was added and the volume was made up to $50 \mathrm{~mL}$ using distilled water. The absorbance was read at $507 \mathrm{~nm}$ for each solution using UV-Visible Spectrophotometer. For determination the total chromium concentration, initially standard $\mathrm{Cr}$ (III) solution with the concentration of $(1 \mathrm{mg} / \mathrm{L})$ was prepared by adding $0.28230 \mathrm{~g}$ of $\mathrm{K}_{2} \mathrm{Cr}_{2} \mathrm{O}_{7}$ to $50 \mathrm{~mL}$ of distilled water, then saturated solution of $\mathrm{Na} 2 \mathrm{~S}(1 \mathrm{~mL})$ and $1 \mathrm{ml}$ of $2.5 \mathrm{M} \mathrm{H}_{2} \mathrm{SO}_{4}$ were added, then the mixture was boiled for $5 \mathrm{~min}$ and diluted to $100 \mathrm{~mL}^{31}$. From the obtained solution a series of $10,20,30,40,50,60,70$ and 80 $\mu \mathrm{g} / \mathrm{L} \mathrm{Cr}$ (III) solutions were prepared and treated as described in the procedure above. The Absorbance was read at $507 \mathrm{~nm}$ for each solution using UV-Visible Spectrophotometer and a calibration curve was constructed.

\section{Removal of total chromium from tannery wastewater samples using Cactus powder}

The $\mathrm{pH}$ of $33 \mathrm{~mL}$ of wastewater in a beaker was adjusted at 8 then $0.198 \mathrm{~g}$ of cactus powder was added. The solution was stirred for an hour and then allowed to stand overnight. $500 \mu \mathrm{g} / \mathrm{L}$ of supernatant was taken from the sample and transferred to 50-mL Erlenmeyer flask, then the total chromium concentration was measured using to the procedure described above.

\section{RESULTS AND DISCUSSIONS}

Determination of $\mathrm{Cr}(\mathrm{VI})$ concentrations in tannery wastewater before treatment

The first step of this work was determining the concentration of $\mathrm{Cr}(\mathrm{VI})$ in tannery wastewater. This was performed spectrophotometricaly using the method developed in literature ${ }^{30}$. According to this method, 1.5-diphenylcarbazide is oxidized to 1.5-diphenylcarbazone by the action of $\mathrm{Cr}(\mathrm{VI})$ in acidic media producing a complex with chromium having red-violet color. The produced complex absorbs visible light with the wavelength of $540 \mathrm{~nm}$. For quantitative determination of $\mathrm{Cr}(\mathrm{VI})$ concentration a calibration curve was constructed. For this purpose, absorbance was measured for $\mathrm{Cr}(\mathrm{VI})$ solutions of different concentrations after adding the ligand (1.5-diphenyl carbazide) to each solution. The obtained values of absorbance were plotted against concentration of $\mathrm{Cr}(\mathrm{VI})(\mathrm{ppm})$. The curve obtained was linear with correlation coefficient $\mathrm{R}^{2}$ equal 0.9959 , which indicated a positive linear relationship between the parameters (Figure 2). 


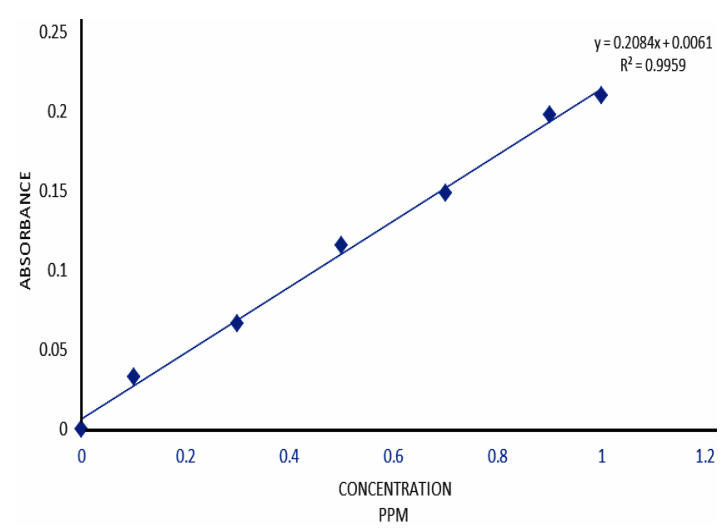

Fig. 2. Calibration curve for determination of $\mathrm{Cr}(\mathrm{VI})$ concentration

As a result of the work, the concentration of $\mathrm{Cr}(\mathrm{VI})$ in tannery wastewater obtained from local Palestinian Leather factory was determined to be $8.1 \mathrm{ppm}$. This value exceeds the level declared by International environmental standards according to which the chromium concentration in wastewater should not exceed $5 \mathrm{ppm}$ for $\mathrm{Cr}$ (III) and $0.05 \mathrm{ppm}$ for $\mathrm{Cr}(\mathrm{VI})^{31}$. This result confirms the need for treatment of tannery wastewater using technically feasible, cheap and environmentally safe method for removing toxic chromium ions.

\section{Removal of $\mathrm{Cr}(\mathrm{VI})$ from tannery wastewater using cactus powder}

The next step of work was evaluating the efficiency of using cactus powder as adsorbent for chromium removal from tannery wastewater and studying the effects of adsorption conditions such as $\mathrm{pH}$, adsorbent dosage and contact time on the percentage removal. For this purpose, samples of tannery wastewater were treated with cactus powder under different conditions $(\mathrm{pH}$, adsorbent dosage, contact time), after what the concentration of chromium was determined. The efficiency of cactus powder was expressed as percentage removal of $\mathrm{Cr}$ ions which was calculated by equation (1) below:

$\%$ Removal $=\frac{\mathrm{Ci}-\mathrm{Cf}}{\mathrm{Ci}} \times 100 \%$

Where $\mathrm{Ci}$ and $\mathrm{Cf}$ are the concentrations of the $\mathrm{Cr}$ ions before and after treatment with cactus, respectively.

Determination the Effect of $\mathrm{pH}$ on the $\mathrm{Cr}(\mathrm{VI})$ removal The adsorption process was performed at different values of $\mathrm{pH}$ in the range 2-10 at fixed adsorbent dosage (6.0 g/L) and contact time (1 hour). The results are presented in Figure 3.

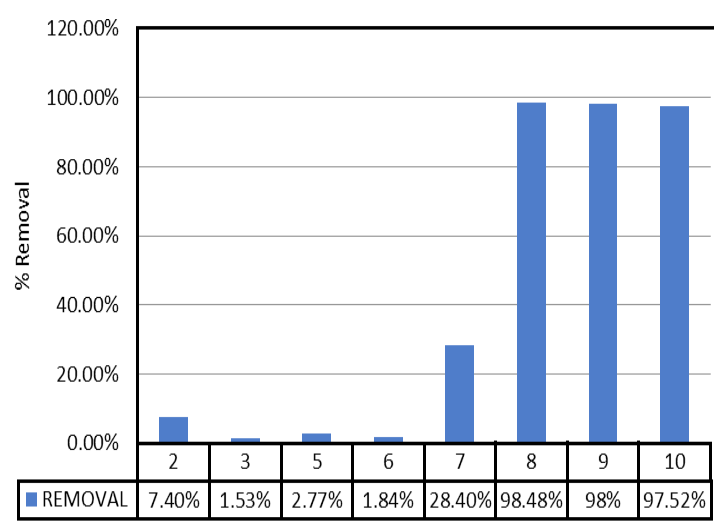

Fig. 3. Percentage removal of $\mathrm{Cr}(\mathrm{VI})$ by adsorption on cactus at different values of $\mathrm{pH}$ (room temperature, overnight and adsorbent dosage $6.0 \mathrm{~g} / \mathrm{L}$ )

From the figure above, it can be noted that at acidic $\mathrm{pH}$ the percentage removal of $\mathrm{Cr}(\mathrm{VI})$ was low, while it significantly increased in basic media to reach its maximum value at $\mathrm{pH}$ of 8 that was $98.48 \%$, after that it decreased. These observations are in agreement with the mechanism proposed by ${ }^{32}$ that is adsorption-charge neutralization and adsorption bridging mechanisms in coagulation-flocculation processes. Basing on the results obtained, the optimum value of $\mathrm{pH}$ was found to be 8 and this $\mathrm{pH}$ was used for the subsequent analyses.

In order to compare the efficiencies of cactus and calcium carbonate adsorbents for $\mathrm{Cr}(\mathrm{VI})$ removal, two separate series of chromium removal experiments were performed using cactus powder as adsorbent in one and calcium carbonate in the other within $\mathrm{pH}$ range 3-11. Comparison of the results shown in Fig. 4 for cactus and $\mathrm{CaCO}_{3}$ enables to confirm that $\mathrm{CaCO}_{3}$ exhibited relatively high percentage removal under both acidic and basic $\mathrm{pH}$ values, while the highest percentage removal of chromium using cactus was obtained at basic $\mathrm{pH}$ values. The percentage removal using cactus was higher than that of $\mathrm{CaCO}_{3}$ at this $\mathrm{pH}$ range, with adsorbent dosage $(6 \mathrm{~g} / \mathrm{L})$ five times less than that for $\mathrm{CaCO}_{3}(30 \mathrm{~g} / \mathrm{L})$.

\section{Determination the Effect of adsorbent dosage on the $\mathrm{Cr}(\mathrm{VI})$ removal}

Samples of wastewater were treated with different amounts of cactus powder at fixed $\mathrm{pH}$ 
and contact time. The amount of adsorbent ranged from 2.0-17.8 $\mathrm{g} / \mathrm{L}$. The value of $\mathrm{pH}$ was adjusted at 8 which was shown to be the optimum. The results are demonstrated in Fig. 5. The percent removal of $\mathrm{Cr}(\mathrm{VI})$ increased to reach the maximum value of $99 \%$ at $0.198 \mathrm{~g} / 33 \mathrm{~mL}(6.0 \mathrm{~g} / \mathrm{L})$, and the subsequent increase in adsorbent dosage resulted in gradual decrease in removal. These results are consistent with previous studies ${ }^{32}$, where they were explained by the fact that in the beginning, the increase of adsorbent dosage results in the increase of negatively charged sites of cactus polyelctrolyte and thus the positive metal ions aggregate and acquire enough size to settle, but after the maximum is reached, the increase in adsorbent dosage leads to respread of aggregated particles on the larger sorbent surface area and particle settling is disrupted and as a result the particles remain in suspension.

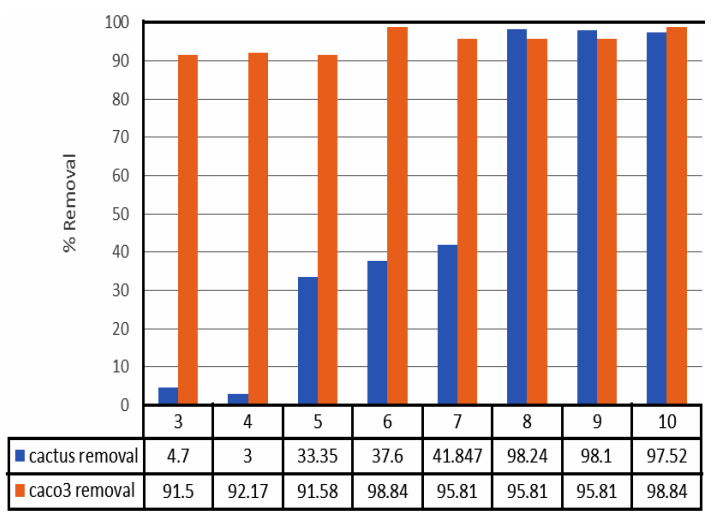

Fig. 4. Removal of chromium (VI) by Cactus and $\mathrm{CaCO}_{3}$ adsorbents at different $\mathrm{pH}$ values and at dosage equal to 6.0/L for cactus and $30.0 \mathrm{~g} / \mathrm{L}$ for $\mathrm{CaCO}_{3}$

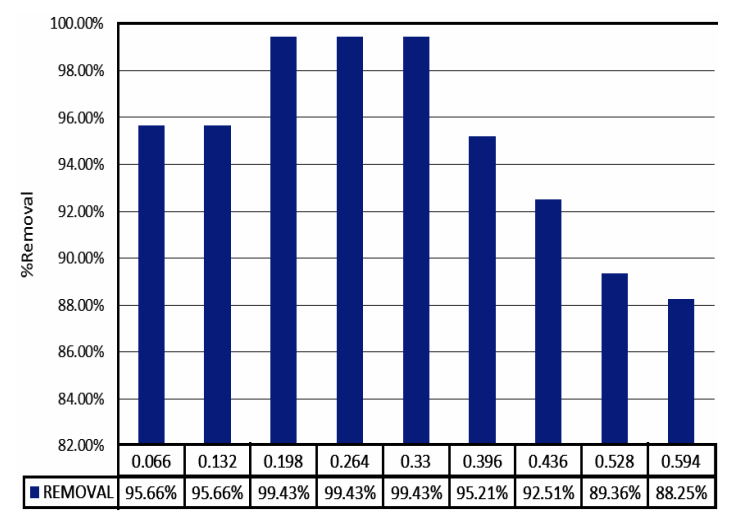

Fig. 5. Percentage removal of $\mathrm{Cr}(\mathrm{VI})$ by adsorption on cactus as a function of adsorbent dosage at room temperature and $\mathrm{pH}$ of 8

Determination of the effect of contact time on the $\mathrm{Cr}(\mathrm{VI})$ removal

The removal of $\mathrm{Cr}(\mathrm{VI})$ using cactus with
$6.0 \mathrm{~g} / \mathrm{L}$ adsorbent dosage and $\mathrm{pH}$ of 8 at different time intervals was studied. The results are presented in Fig. 6. The adsorbent achieved maximum adsorption for $\mathrm{Cr}(\mathrm{VI})$ at contact time equal to 60 $\mathrm{min}$, where the percentage removal of $\mathrm{Cr}(\mathrm{VI})$ was $99.9 \%$. The chromium removal increased to reach the maximum value after 60 min stirring, and thereafter slightly decreased. Majority of metal ions in the wastewater are attracted to adsorption sites of Cactus with opposite charges resulting in enhanced adsorption percent by the end of the first 60 mintue. However, after that, progressive attachment of ions to these sites with constant amount of sorbent, leads to limited number of free adsorption sites, and as a result, the process reaches an equilibrium state ${ }^{32}$.

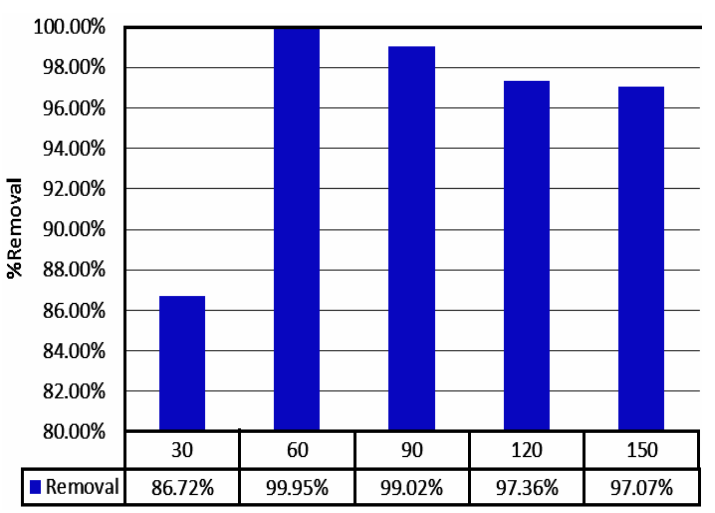

Fig. 6. Percentage removal of $\mathrm{Cr}(\mathrm{VI})$ by adsorption on cactus as a function of contact time, adsorbent dosage 6.0/L and $\mathrm{pH}=8$

Basing on the results obtained from the current investigation, it can be demonstrated that the optimum conditions for $\mathrm{Cr}(\mathrm{VI})$ removal using cactus powder adsorbent are the following: $\mathrm{pH}-8$, adsorbent dosage-6.0 g/L and contact time- 60 minute. These conditions were applied for subsequent steps of analysis.

Removal of total chromium using cactus powder

For determination of total chromium a spectrophotometric method using sulphanilic acid and $\mathrm{N}, \mathrm{N}$-dimethylaniline was used ${ }^{8}$. In this method, $\mathrm{Cr}(\mathrm{III})$ is initially oxidized to $\mathrm{Cr}(\mathrm{VI})$ with bromine water in basic media. Then, $\mathrm{Cr}(\mathrm{VI})$ oxidizes hydroxylamine at $\mathrm{pH}$ of 4 to nitrite ion that reacts with sulphanilic acid converting it to diazonium salt, which is attached to N, $\mathrm{N}$-dimethylaniline in basic solution to produce methyl orange, that orange color when acidified and absorbs the visible light with wavelength of $507 \mathrm{~nm}$.

Absorbance was measured for total chromium solutions of different concentrations. The 
obtained values of absorbance were plotted against concentration of total chromium ( $\mu \mathrm{g} / \mathrm{L})$ to construct a calibration curve. The correlation coefficient $\left(R^{2}\right)$ of obtained curve was 0.999 , which indicated a strong positive linear relationship between the parameters (Figure 7).

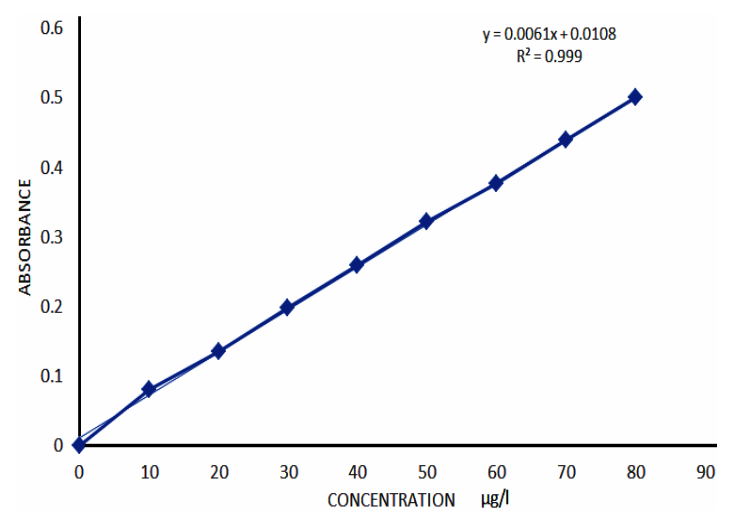

Fig. 7. calibration curve for determination of concentration of total chromium

The concentration of total chromium in untreated tannery wastewater samples was determined using the obtained equation from calibration curve, and was found to be to 41.109 ppm, as shown in the Table below. Thereby the concentration of $\mathrm{Cr}$ (III) have been calculated to be equal to $33.0 \mathrm{ppm}$. This value exceeds the level declared by International environmental standards (5 ppm for $\mathrm{Cr}(\mathrm{III})^{31}$. After that, samples of wastewater were treated with cactus powder $(6.0 \mathrm{~g} / \mathrm{L})$, at $\mathrm{pH}$ of 8 , for $60 \mathrm{~min}$ ) and then the total chromium was determined. The results are shown in the table below.

These presented results demonstrate the high efficiency of cactus powder in removing chromium ions from tannery wastewater, where the percentage removal was $97.37 \%$ for total chromium, $98.8 \%$ for toxic $\mathrm{Cr}(\mathrm{VI})$ and $97.0 \%$ for $\mathrm{Cr}(\mathrm{III})$.

In the Table 2 below, the percentage removal of $\mathrm{Cr}(\mathrm{VI})$ using various methods reported in some previous works are presented. Comparing the data shown in Table 2 with the results of this work, in addition to the previously mentioned advantages of using cactus as adsorbent for chromium ions, obviously prove the advantage of using cactus for chromium removal over other sorbents and methods used in some previous works. Therefore cactus can be recommended as an efficient, safe and cheap adsorbent for the treatment of tannery wastewater.

Table 1: Percentage removal of total chromium at optimum conditions ( $\mathrm{pH}=8$, and $6 . \mathrm{g}$ cactus/L)

\begin{tabular}{|c|c|c|c|}
\hline & $\begin{array}{l}\text { Concentration of total } \\
\text { chromium (ppm) }\end{array}$ & $\begin{array}{l}\text { Concentration of } \\
\text { chromium(VI) (ppm) }\end{array}$ & $\begin{array}{c}\text { Concentration of } \\
\text { chromium III) (ppm) }\end{array}$ \\
\hline Untreated wastewater & 41.1 & 8.1 & 33.0 \\
\hline Treated wastewater & 1.08 & 0.09 & 0.99 \\
\hline$\%$ Removal & 97.37 & 98.80 & 97 \\
\hline \multicolumn{4}{|c|}{$\begin{array}{l}\text { Table 2: Percentage removal of } \mathrm{Cr}(\mathrm{VI}) \text { as reported in some previous works using } \\
\text { different methods and sorbents }\end{array}$} \\
\hline Method or sorbent & & & \%removal of $\mathrm{Cr}(\mathrm{VI})$ \\
\hline \multicolumn{3}{|c|}{ Chemical coagulation using aluminum sulphate and ferric chloride ${ }^{3}$} & $74-94$ \\
\hline \multicolumn{3}{|c|}{ Adsorption onto bentonite clay ${ }^{14}$} & 93 \\
\hline \multicolumn{3}{|l|}{ Sedimentation ${ }^{11}$} & 83.2 \\
\hline \multicolumn{3}{|c|}{ Natural, protonated and thermally treated Ectodermis of Opuntia ${ }^{19}$} & 77 \\
\hline \multicolumn{4}{|c|}{ Natural polyelectrolyte, extracted from the cactus Opuntia ficusindica, with either: } \\
\hline \multicolumn{3}{|l|}{ a- aluminum sulfate or } & a-83 \\
\hline \multicolumn{3}{|l|}{ b- ferric chloride ${ }^{10}$} & $b-91.22$ \\
\hline \multicolumn{3}{|c|}{ Lime/bittern coagulation and activated carbon adsorption ${ }^{13}$} & 99.7 \\
\hline \multicolumn{3}{|c|}{ Polyacrylamide-grafted coconut coir pith ${ }^{15}$} & 99.4 \\
\hline
\end{tabular}

\section{CONCLUSION}

The results of the present work showed that Cactus acts as an excellent adsorbent for carcinogenic $\mathrm{Cr}(\mathrm{VI})$ in basic medium. The percentage removal of $\mathrm{Cr}(\mathrm{VI})$ using Cactus reached $98.8 \%$ and 
$97.0 \%$ for $\mathrm{Cr}(\mathrm{III})$ under the optimum conditions $(\mathrm{pH}-8$, contact time-60 min and adsorbent dos age- $6.0 \mathrm{~g} / \mathrm{L}$ ). Cactus has adsorbent capacity close to $\mathrm{CaCO}_{3}$, requiring dosage lower than $\mathrm{CaCO}_{3}$ in basic medium. Thus Cactus can be used as low-cost alternative to other adsorbents since it readily available in nature giving an advance of it is biodegradability and formation lower sludge.

\section{ACKNOWLEDGMENT}

The authors of this paper would like to thank the Deanship of Graduate Studies and Scientific Research at Palestine Polytechnic University for their support in conducting this research.

\section{Conflict of interest}

Authors of this paper have no conflict of interest.

\section{REFERENCES}

1. Feng, J.; Sun, Y.; Zheng, Z.; Zhang, J.; Shu, L. I. Journal of Environmental Sciences., 2007, 19(12), 1409-1415.

2. Ilou, I.; Souabi, S.; Digua, K. Int. J. Environm. Sci. Developm., 2014, 3(5), 1706-1715.

3. Song, Z.; Williams, C.; Edyvean, R. Desalination., 2004, 164(3), 249-259.

4. Owlad, M.; Aroua, M. K.; Daud, W. Water, Air, and Soil Pollution., 2009, 200(1-4), 59-77.

5. Oliveira, H. Journal of Botany., 2012, 2012, 1-8.

6. Becquer, T.;, Quantin, C.; Sicot, M.; Boudot, J. P. Science of the Total Environment., 2003, 301(1-3), 251-261.

7. Peralta-Videa, J.R.; Lopez, M. L.; Narayan, M.; Saupe, G.; Gardea-Torresdey, J. The International Journal of Biochemistry \& cell Biology., 2009, 41(8-9), 1665-1677.

8. Chandrashekhara, K.; Gopalakrishna, B. N.; Nagaraj, P. Indian Journal of Chemical Technology., 2015, 22, 78-81.

9. Aregu,M.B.;Asfaw, S.L.;Khan, M.M. Environmental Systems Research., 2018, 7(1), 10.

10. Gomes, L.; Troiani, E. P.; Malpass, G. R.; Nozaki, J. Desalination and Water Treatment., 2016, 57(22), 10181-10187.

11. Song, Z.; Williams, C.; Edyvean, R. Water Research., 2000, 34(7), 2171-2176.

12. Mane, P. C.; Bhosle, A. B.; Jangam, C. M.; Mukate, S. V. J. Nat. Prod. Plant Resour., 2011, 1(1), 75-80.

13. Ayoub, G.; Hamzeh, A.; Semerjian, L. Desalination., 2011, 273(2-3), 359-365.

14. Tahir, S.; Naseem, R. Separation and Purification Technology., 2007, 53(3), 312-321.

15. Unnithan, M.R.; Vinod, V.; Anirudhan, T. Industrial \& Engineering Chemistry Research., 2004, 43(9), 2247-2255.

16. Hashem, A.; Akasha, R. A.; Ghith, A.; Hussein, D. A. Energy Educ. Sci. Technol., 2007, 19, 69-86.

17. Ravikumar, K.; Deebika, B.; Balu, K. Journal of Hazardous Materials., 2005, 122(1-2), 75-83.
18. Barrera, H.; Ureña-Núñez, F.; Bilyeu, B.; Barrera-Díaz, C. Journal of Hazardous Materials., 2006, 136(3), 846-853.

19. Batista, A. M.; Mustafa, A. F.; McAllister, T.; Wang, Y.; Soita, H.; McKinnon, J. J. Journal of the Science of Food and Agriculture., 2003, 83(5), 440-445.

20. Rodríguez-Felix, A.; Cantwell, M. Plant Foods for Human Nutrition., 1988, 38(1), 83-93.

21. Malainine, M. E.; Dufresne, A.; Dupeyre, D.; Vignon, M. R.; \& Mahrouz, M. Zeitschrift für Naturforschung C., 2003, 58(11-12), 812-816.

22. Mohamed-Yasseen, Y.; Barringer, S.A.; Splittstoesser, W.E. Journal of Arid Environments., 1996, 32(3), 347-353.

23. Palomino, G.; Martínez, J.; Méndez, I.; MuñozUrías, A.; Cepeda-Cornejo, V.; PimientaBarrios, E. Caryologia., 2016, 69(1), 82-89.

24. Stintzing, F.C.; Carle, R. Molecular nutrition \& food research., 2005, 49(2), 175-194.

25. Gad, A.S.; Attia, M.; Ahmed, H. Journal of American Science., 2010, 6, 79-87.

26. Fox, D. I.; Pichler, T.; Yeh, D. H.; Alcantar, N. A. Environmental Science \& Technology., 2012, 46(8), 4553-4559.

27. Barka N.; Abdennouri O.K., Makhfouk M.E. J.e Taiwan Instit. Chem. Eng., 2013, 44, 52-60.

28. Kumar, R.; Barakat, M. Chemical Engineering Journal., 2013, 226, 377-383.

29. Sawalha,H.; Alsharabaty, R.; Sarsour, S.; Al-Jabari, M. Journal of Environmental Management., 2019, 251, 109596-109615.

30. Kocurek, P.A.V. E. L.; Vaskova, H.; Kolomaznik, K. A. R. E. L.; Barinova, M. Wseas. Trans. Environ. Dev., 2015, 11, 256-263.

31. Jabari, M.; Aqra, F.; Shahin, S.; \& Khatib, A. Chemical Speciation \& Bioavailability., 2009, 21(3), 185-191.

32. Nharingo, T.; Zivurawa, M.; Guyo, U. International Journal of Environmental Science and Technology., 2015, 12(12), 3791-3802. 